\title{
SEASONAL CHANGES IN HYDROLOGY AND THE DISTRIBUTION OF PLANKTON IN THE BATHURST HARBOUR ESTUARY, SOUTHWESTERN TASMANIA, 1988-89
}

\author{
by G. J. Edgar and G. R. Cresswell
}

(with two tables and eleven text-figures)

EDGAR, G.J. \& CRESSWELL, G.R., 1991 (20:xii): Seasonal changes in hydrology and the distribution of plankton in the Bathurst Harbour estuary, southwestern Tasmania, 1988-89. Pap. Proc. R. Soc. Tasm. 125:61-72. https://doi.org/10.26749/rstpp.125.61

ISSN 0080-4703. Zoology Department, University of Tasmania, GPO Box 252C, Hobart, Tasmania, Australia 7001 (GJE); CSIRO Division of Oceanography, Marine Laboratories, GPO Box 1538, Hobart, Tasmania, Australia 7001 (GRC).

The hydrology and abundance of planktonic organisms ( $>20 \mu \mathrm{m}$ size) were surveyed at various sites in the Bathurst Harbour/Port Davey estuary on five occasions between October 1988 and July 1989, and the hydrology again surveyed in February 1991. In winter, the period of peak freshwater outflow, a brackish surface layer $(\approx 15 \%$ ) was present to a depth of $\approx 4 \mathrm{~m}$ throughout the estuary. This surface layer was present to a reduced depth in other seasons, except during summer, when the halocline broke down and surface salinities of $\approx 29 \% \bullet$ in 1989 and $\approx 25 \%$ in 1991 prevailed. Bottom waters were close to fully marine $(\approx 33 \%$ ) throughout the year. Surface waters in Bathurst Harbour were found to be extremely depleted in nitrates $(<0.1 \mu \mathrm{M})$. Oxygen levels were also very low ( $\approx 35 \%$ saturation) during the 1989 summer which was unusually dry, but were near full saturation during the other sampling periods.

The plankton communiry in Bathurst Harbour contained very few taxa, particularly during the winter months. The dinoflagellate Dinophysis acuminata comprised $>99 \%$ of total phytoplankton numbers in October 1988 and July 1989, while the copepods Gladioferens inermis and Oithona australis and the appendicularian Oikopleura sp. numerically dominated the zooplankton community. Dinoflagellates and copepods both occurred in high densities. The distribution of diatoms within the estuary was inversely related to the distribution of dinoflagellates; diatoms occurred in low densities relative to dinoflagellates in Bathurst Harbour outside the summer months, but occurred in much higher densities than dinoflagellates in the waters of Port Davey throughout the year.

Key Words: Bathurst Harbour, Port Davey, estuary, hydrology, salinity, temperature, oxygen saturation, nitrate concentration, phytoplankton, zooplankton, Gladioferens inermis, Dinophysis acuminata, Oithona australis, Tasmania.

\section{INTRODUCTION}

A single large sheltered inlet, Port Davey, is present along the $250 \mathrm{~km}$ section of Tasmanian coast between Macquarie Harbour on the western coast and Recherche Bay on the southeastern coast. This inlet was formed by a marine transgression into the lower reaches of the principal rivers of the region, the Davey and Old Rivers. The Old River empties into Bathurst Harbour, which is connected to Port Davey via Bathurst Channel. Several other river systems, notably the Spring and North Rivers, also feed into Bathurst Harbour and Bathurst Channel.

The Port Davey/Bathurst Harbour estuarine system differs from others in southern Australia because it is the only large estuary fed by unrestrained rivers, without road access, and without significant human impact (except, perhaps, for landscape modification due to increased fire frequency and two small tin leases operated beside Moth Creek near Melaleuca Inlet). The permanent population within the $2000 \mathrm{~km}^{2}$ catchment area consists of two tin miners, with a transient population of fishermen, bushwalkers, sailors and airborne tourists reaching a daily maximum of $\approx 100$ during summer.

Because of the isolation of the area, nothing was known of the hydrology of Port Davey or the Bathurst Harbour estuary (defined in this study as including Bathurst Harbour and associated estuarine inlets, Bathurst Channel, and the section of Port Davey east of Breaksea Island), other than that the surface waters were highly stained by tannins and that the freshwater entering the system had an ionic composition similar to seawater (Buckney \& Tyler 1973) before 1977. In that year, the Tasmanian Government commissioned the South West Tasmania Resources Survey, and, as part of this, two hydrological surveys were conducted in the region, the first between 31 December 1977 and 6 January 1978 (Thomson 1978a) and the second from 16 to 20 July 1978 (Thomson 1978b). During both surveys, water temperature, salinity, $\mathrm{pH}$ and dissolved oxygen concentrations were measured at one to three depths at a number of stations in Kelly Basin, Port Davey, Bathurst Channel, Bathurst Harbour and Melaleuca Inlet. Thomson (1978a,b) found during his surveys that Port Davey and Bathurst Harbour were more marine than previously anticipated, and that Bathurst Harbour and Bathurst Channel were highly stratified, with a brackish layer overlying marine waters which extended to a depth of $4 \mathrm{~m}$ in winter but to only $2 \mathrm{~m}$ in summer.

Virtually nothing was known about the planktonic assemblages within the estuary prior to the present study; the only effort to collect plankton from the Bathurst Harbour estuary was made by the Biological Society of the University of Tasmania, during a summer 1969 field trip. The Biological Society collected an unusual cyclopoid copepod from the western outlet of Bathurst Channel but was unsuccessful in attempts to collect plankton from sites further upstream (Ong 1969); they consequently concluded that the estuary has a negligible abundance of plankton. This absence of studies in Bathurst Harbour and Bathurst Channel contrasts with the considerable information available on the plankton communities in the Derwent and Huon River estuaries (Nyan Taw \& Ritz 1978, 1979; Ong 1967), the two other large estuaries in southern Tasmania.

The hydrological and plankton investigations described here were partly intended to extend Thomson's hydrological 
results and provide a preliminary account of near-surface $(<1 \mathrm{~m})$ zooplankton and phytoplankton within the Bathurst Harbour estuary. A more important function of these surveys was to form part of a larger study aimed at quantifying seasonal changes in the major physico-chemical and biological features of the estuarine ecosystem. Information on the mobile benthic fauna and fish in the Bathurst Harbour estuary is presented in associated papers (Edgar 1991a,b). Such information is particularly important for the optimal management of the region because the data provides a baseline against which any future changes can be compared. The study also provides unique information for southern Australia on the natural, pre-anthropogenically disturbed state of a large estuary.

\section{METHODS}

\section{Area Investigated}

The Bathurst Harbour estuary contains three major geographical components (fig. 1): a section of a coastal embayment (Port Davey), a sheltered estuarine basin (Bathurst Harbour), and the heavily indented connecting passage. This passage, Bathurst Channel, is approximately $1 \mathrm{~km}$ wide and traverses $12 \mathrm{~km}$ through quartzitic hills. It superficially resembles a fjord, and was initially considered as one; however, it is now recognised as a drowned river valley of the trellis type (Baker \& Ahmad 1959). Hydrographic charts of the area (Australian Admiralty Charts AUS 175 and AUS 176) surveyed in 1922 indicate that the bottom of Bathurst Channel varies from 15 to $40 \mathrm{~m}$ depth, but that a relatively shallow sill $(\approx 12 \mathrm{~m})$ at its western end separates the channel from the deeper waters of Port Davey and the open sea. At its eastern end, Bathurst Channel forms the outlet for Bathurst Harbour, a large $(\approx 7 \mathrm{~km}$ long, $\approx 5 \mathrm{~km}$ wide) basin, surrounded on all sides by hills. The floor of Bathurst Harbour is flat, rising gradually from $7 \mathrm{~m}$ deep in the eastern sector to slightly shallower depths $(6 \mathrm{~m})$ near its western outlet (Australian Admiralty Chart AUS 176). The area was probably once a large buttongrass plain which became inundated by marine water, following recent sea level rises.

\section{Hydrology}

Hydrological data were collected on six occasions between 8 October 1988 and 23 February 1991, at ten stations along a transect running from the mouth of the Old River in Bathurst Harbour to the western side of Breaksea Island in Port Davey, and at five stations along a transect running along Melaleuca Inlet from the Boat Landing in Melaleuca Lagoon to Celery Top Island (fig. 1). Additional hydrological data were collected from three sites along the Old River (First Bend, Old River 8111 Tasmap grid reference DN374024; Huon Pines, DN378032; Islet, DN386037) on 27 November 1988 and 25 July 1989, and four sites on the Davey River (Carvers Point Shoal, Port Davey 8011 Tasmap grid reference DN130135; Settlement Point, DN118150; Foot Track Islet, DN 122204; Davey Gorge, DN132212) on 12 February 1989. At each station salinities and water temperatures were recorded using a Hamon Salinometer at $1 \mathrm{~m}$ intervals for the first $10 \mathrm{~m}$ below the water surface and then at $2 \mathrm{~m}$ intervals to the bottom. Dissolved oxygen concentrations (measured using a Yeocal $\mathrm{O}_{2}$-meter) and light levels (PAR measured with a Licor photometer) were also measured on 23 February

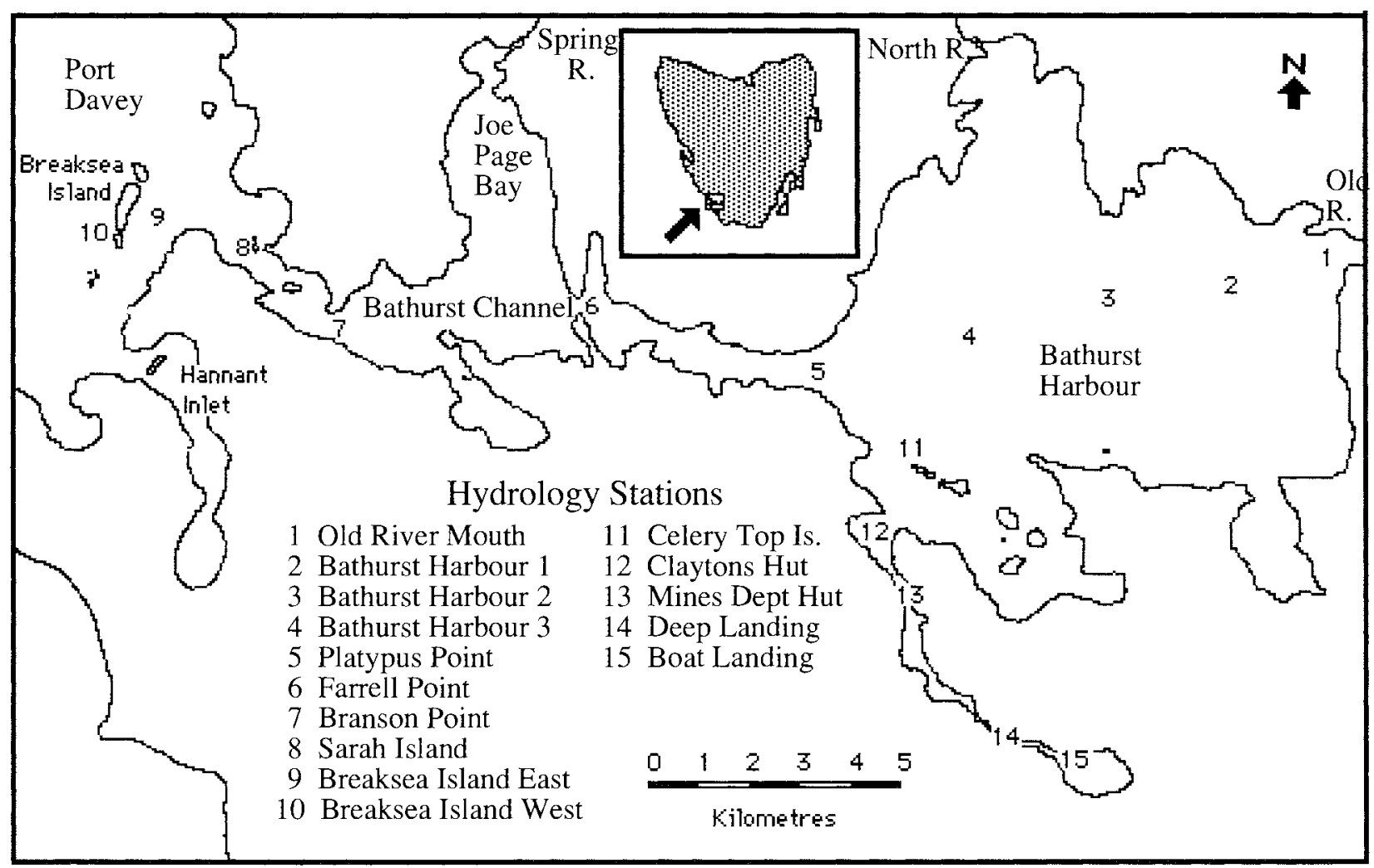

FIG. 1 - Hydrological stations surveyed during the study. 
1991 at these sites and depths. Water samples were collected for nitrate analysis at Stations 1 (Old River Mouth), 3 (Bathurst Harbour 2), 5 (Platypus Point), 6 (Farrell Point), 8 (Sarah Island) and 9 (Breaksea Island East). At these stations a Niskin bottle was triggered at depths of 0,2 and $0.5 \mathrm{~m}$ above the bottom, and at 4 and $6 \mathrm{~m}$ if water depths allowed. The sample was then retrieved and preserved, using $\mathrm{HgCl}_{2}$ for analysis of $\mathrm{NO}_{2}{ }^{-}$and $\mathrm{NO}_{2}{ }^{-}+\mathrm{NO}_{3}{ }^{-}$in the laboratory with a Technicon AutoAnalyser (Department of the Environment). Water samples were also collected at various depths and seasons from Stations 1, 3, 5 and 8 for oxygen and salinity analysis, using the laboratory methods of Major et al. (1972). Oxygen samples were transferred from the Niskin to a BOD bottle on the boat, fixed immediately by the addition of $\mathrm{MnSO}_{4}, \mathrm{KI}-\mathrm{KOH}$ and $\mathrm{H}_{2} \mathrm{SO}_{4}$, and stored in the dark. The laboratory salinity measurements were used to calibrate the in situ salinity data.

Hydrological data obtained during the study should encompass normal seasonal extremes within the estuary; one survey (8 October 1988) was conducted during a month of exceptionally high rainfall, the wettest month on record at Melaleuca, while another (8 February 1989) was conducted during the middle of a dry summer (D. King, meteorological records).

\section{Plankton}

Plankton samples were collected using a $220 \mathrm{~mm}$ diameter, $20 \mu \mathrm{m}$ mesh plankton net which was slowly towed at $\approx 0.3 \mathrm{~m}$ depth behind a runabout dingy for 120 s intervals. Collections were made at most of the stations at which hydrological data were collected (fig. 1) along the transect from Bathurst Harbour to Port Davey: Stations 3 (central Bathurst Harbour), 5 (Platypus Point), 6 (Farrell Point), 7 (Branson Point), 8 (Sarah Island), 9 (Breaksea Island East) and 10 (Breaksea Island West). Two replicate samples were collected at each site during the December, February, May and July surveys, with unreplicated samples being made on 8 October 1988 and no sample being collected off Branson Point on that date. Once each sample was collected and the $50 \mathrm{ml}$ sample bottle unscrewed from the net, the contents were preserved by adding buffered formalin $(\approx 2 \% \mathrm{v} / \mathrm{v})$. A General Oceanics Model 2030 Digital Flowmeter, which was fitted into the mouth of the net during the 25 July 1989 survey, indicated that the mean velocity of water passing through the centre of the net was $0.115 \mathrm{~m} / \mathrm{s}$, hence the net filtered $\approx 0.5 \mathrm{~m}^{3}$ of water during each $120 \mathrm{~s}$ sampling period.

In the laboratory, two $0.3 \mathrm{ml}$ aliquots from each sample were placed under cover slips on separate microscope slides, and the abundances of planktonic taxa recorded while scanning four times across the slides using the $10 \times$ objective of a compound microscope. Whenever the number of zooplanktonic organisms was low (i.e. $<50$ animals were recorded during the scanning of a slide), the zooplankton in the primary sample was also sorted and counted under a dissecting microscope. Plankton counts on microscope slides were converted to total sample counts by multiplying by a factor of 182; the regression $\mathrm{P}=182 \times S\left(\mathrm{n}=11, \mathrm{r}^{2}=0.80\right)$ was calculated from the December data, where $P$ is the zooplankton abundance recorded from a sample by direct count and $S$ is the number of zooplankton taxa recorded during a total of eight traverses across the two slides from each sample. The biomass of zooplankton in each sample was determined by rinsing a $10 \%$ v./v. subsample in freshwater, passing it through a $0.52 \mu \mathrm{m}$ Millepore filter and then calculating the difference between the predried and postdried (at $60^{\circ} \mathrm{C}$ for 2 hours) weight of the filter plus animals.

Our study of the distribution of planktonic plants and animals within the Bathurst Harbour estuary was not aimed at the rotal planktonic communiry; organisms below $1 \mathrm{~m}$ depth or smaller than $20 \mu \mathrm{m}$ mesh size were not collected. The nanoplankton $(2-20 \mu \mathrm{m})$ and picoplankton $(0.5-2 \mu \mathrm{m})$ communities in Bathurst Harbour consequently remain unstudied, while larger fragile flagellates were probably also underrepresented in formalin-preserved samples. It should also be noted that the abundance data, as shown in the various figures, may have been systematically underestimated because (i) the sampling vials attached to the net did not have drainage windows, hence the net could not be washed down and some water with organisms was lost when the sampling vials were unscrewed; and (ii) calculations of the water sieved through the net were based on water passing through the centre of the net, with the reduction in water flow due to drag near the edges of the net not being accounted for. Any errors should, however, be constant for different sites and sampling periods, hence the numerical data can be confidently compared between sites and seasons.

\section{RESULTS}

\section{Hydrology}

Temperature, salinity and nitrate sections in the upper $8 \mathrm{~m}$ along the axis of Bathurst Harbour estuary for the various seasonal surveys are shown in figures 2,3 and 4 . The sections are complemented by the temperature and salinity data (fig. 5) for sites representative of Bathurst Harbour (Bathurst Station 2) and the deep part of Bathurst Channel (Branson Station), which are presented as depth profiles of temperature and salinity. Figure 6 includes the corresponding data for a station representative of the deep part of Macquarie Harbour (from Cresswell et al. 1989). The Bathurst and Macquarie systems will be compared later in this paper.

Water temperatures (fig. 2) varied more in Bathurst Harbour than at the western outlet of Bathurst Channel, presumably because of the large expanse of shallow water in Bathurst Harbour, the highly variable riverine input, and the buffering provided by seawater near the outlet.

Waters in Bathurst Harbour below $5 \mathrm{~m}$ depth (figs 2 and 5) varied only between $12^{\circ}$ and $14^{\circ} \mathrm{C}$ during the spring, autumn and winter sampling surveys, and increased to $\approx 17^{\circ} \mathrm{C}$ during summer. Maximum-minimum thermometers indicated, however, that the annual temperature range $\left(\approx 10-19^{\circ} \mathrm{C}\right)$ for water at $8 \mathrm{~m}$ depth (table 1 ) was greater than that recorded during the surveys.

The deep part of Bathurst Channel, represented by the Branson Station in fig. 5 , showed only a $1.5^{\circ} \mathrm{C}$ temperature range at $30 \mathrm{~m}$ depth. At the surface, however, the temperatures over the various surveys ranged over $10^{\circ} \mathrm{C}$, being $\approx 3^{\circ} \mathrm{C}$ cooler than the bottom waters in winter and $\approx 6^{\circ} \mathrm{C}$ warmer in February 1989.

On most surveys, a well-defined halocline was present in the top $6 \mathrm{~m}$, gradually decreasing in depth from Bathurst Harbour to the western outlet of Bathurst Channel and ceasing to exist outside Breaksea Island (fig. 3). The low river input during February (figs 3 and 5) meant that the surface waters became more saline and the halocline all but 


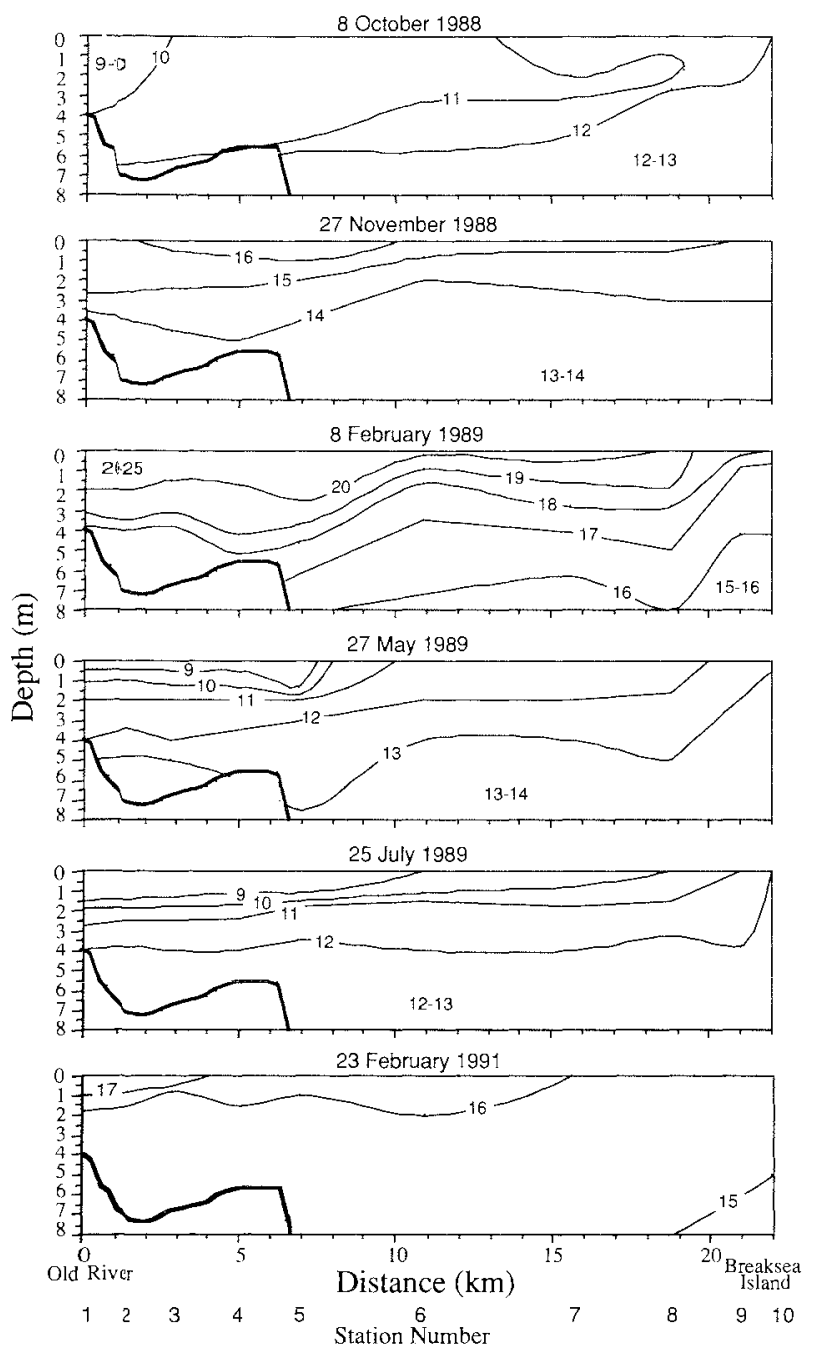

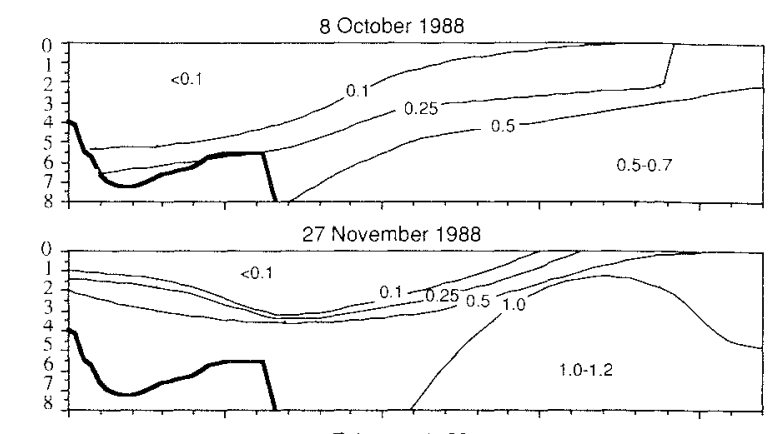
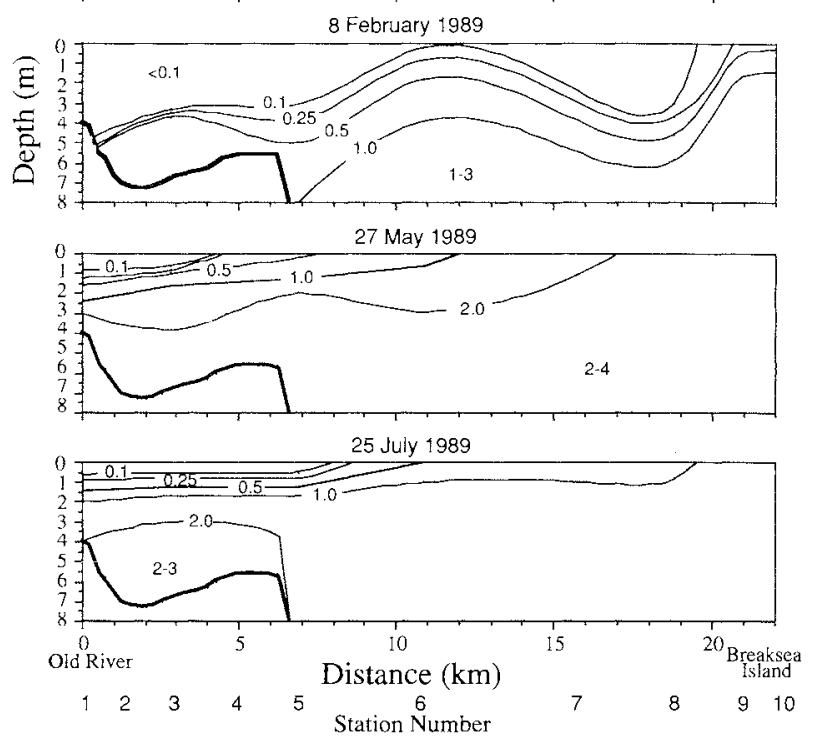

FIG. 3 - Salinity profiles (\%o).

FIG. 2 - Temperature profiles $\left({ }^{\circ}\right)$.

FIG. 2,3\&4-Hydrological sections from the mouth of the Old River to Breaksea Island as recorded during the various field trips. Bathurst Harbour seabed is shown by bold line.

disappeared. Surface salinities in Bathurst Harbour ranged from only 7 to $15 \%$ over the other surveys. Freshwater input into Bathurst Harbour outside the summer months primarily acted to depress the level of the halocline and extend the distance that the brackish layer descended down the estuary, rather than dramatically reduce surface salinities. During the period of peak freshwater outflow in October 1988, the wettest month recorded at Melaleuca (D. King, meteorological records), the halocline was depressed to $6.5 \mathrm{~m}$ depth in Bathurst Harbour, while in other months of the. year marine $(>30 \%)$ water extended to within $\approx 3 \mathrm{~m}$ of the surface. The surface waters of Port Davey between Bathurst Channel and Breaksea Island were brackish during the October survey. Fully marine ( $>34 \%$ ) water maintained a relatively constant depth gradient on all sampling occasions, occurring at a depth of $\approx 5 \mathrm{~m}$ at Sarah Island and gradually sinking along the channel to a depth of $\approx 14 \mathrm{~m}$ at Platypus Point.

On three surveys, the bottom salinities in the eastern and central sectors of Bathurst Harbour were higher than at corresponding depths near Platypus Point in Bathurst Channel. (At $7 \mathrm{~m}$ at Bathurst Harbour 1 on the November,
May and July surveys, the salinities were $34.7 \%$ o, 33.0\% and $34.0 \%$, while at $10 \mathrm{~m}$ at Platypus Point they were only $32.9 \%$, 31.5\% and 33.2\%o, respectively.) Bottom water in Bathurst Harbour was also markedly reduced below marine salinities $(27.5 \%$ ) on the October survey. The bottom water in the harbour was clearly isolated from the marine water of the channel for much of the year, gradually diluting during these periods of isolation by the diffusion and convection of brackish water. Dense intruding marine water replenishes Bathurst Harbour bottom water whenever the halocline at the eastern end of Bathurst Channel approaches close to the surface. Such intrusions of marine water occurred on several occasions during the study period: between 9 October and 27 November 1988, during February, and between 27 May and 25 July 1989.

The bottom water in the deeper sections of Melaleuca Inlet was also isolated from Bathurst Harbour by shallow banks near Claytons Hut for much of the year. On all surveys, the bottom salinities were higher in the deep channel near the Mines Hut than downstream at Claytons Hut, while on 12 October, during peak freshwater outflow, salinities were higher at the Melaleuca Boat Landing at $3 \mathrm{~m}$ 


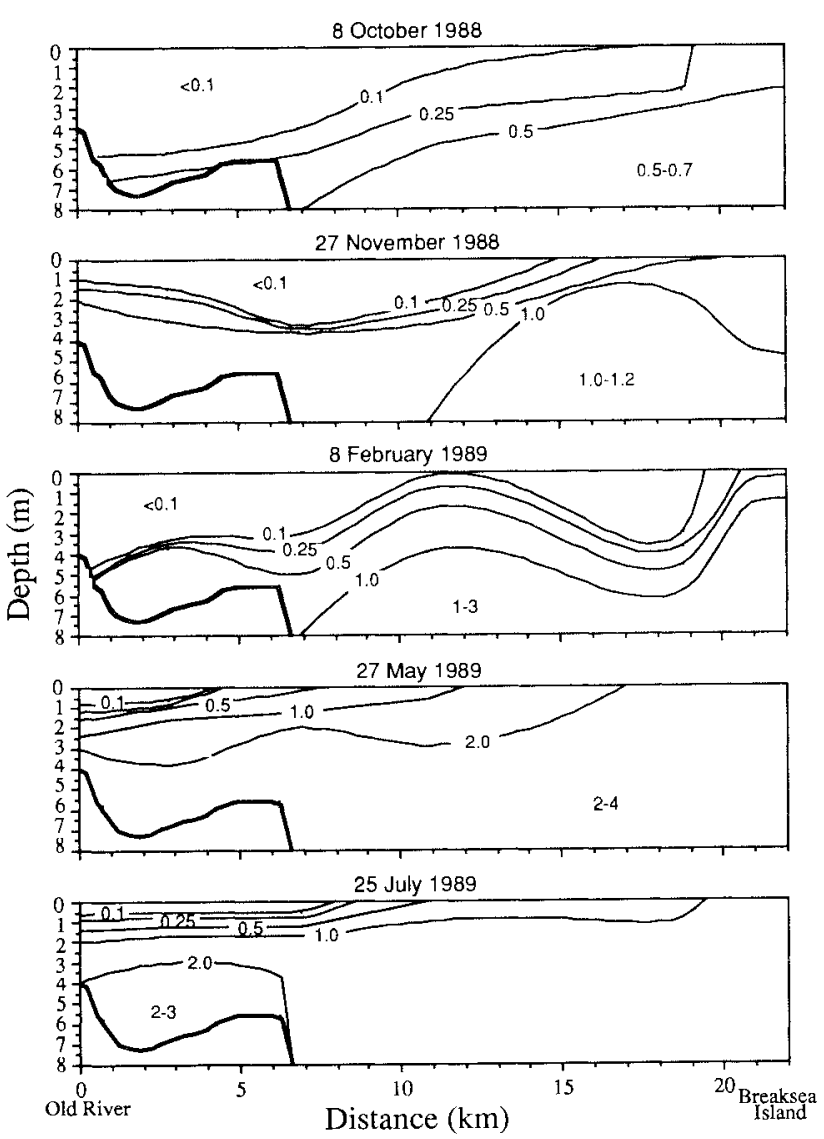

FIG. 4 - Nitrate concentration profiles $(\mu M)$.

depth than at the same depth in Bathurst Harbour at Celery Top Island. During February, water throughout Melaleuca Inlet was quite saline $(>25 \%)$, with no indication of a halocline such as was observed during the other surveys.

Brackish water, and perhaps marine water in summer, enters the Old River as far as the first riffle bank $(2 \mathrm{~km}$ upstream), but is flushed from the shallow $(<1 \mathrm{~m})$ sections of the river during periods of heavy rain. During summer, the only period sampled, marine bottom water was present all the way up the Davey River to the downstream end of the Davey Gorge. Surface waters were close to fresh $(<5 \%$ ) down to the Davey River mouth.

Nitrate concentrations were extremely low in Bathurst Channel and Bathurst Harbour (fig. 4); nitrates were in fact undetectable $(<0.1 \mu \mathrm{M})$ in the surface waters at the eastern end of Bathurst Harbour throughout the study. The Old River apparently provided little nitrate input into Bathurst Harbour; a surface concentration of only $0.6 \mu \mathrm{M}$ was recorded $1 \mathrm{~km}$ up the Old River at the Huon Pines on 25 July 1989.

Nitrate levels increased with depth at all sites, with a maximum recorded concentration of $3.9 \mu \mathrm{M}$ at $6 \mathrm{~m}$ at the Bathurst Harbour 1 station in May. Nitrate concentrations also generally increased towards Port Davey, apart from May and July 1989 when there was a slight reverse trend in waters $>4 \mathrm{~m}$ depth.

During the cooler months, dissolved oxygen concentrations were high throughout Bathurst Harbour (table 2). At the time of the February 1989 survey, however, oxygen concentrations were extremely low at all stations sampled
TABLE 1

Temperature range $\left({ }^{\circ} \mathrm{C}\right)^{*}$ at sites in Bathurst Channel and Bathurst Harbour, 27 November 1988 to 27 July 1989

\begin{tabular}{crc}
\hline Depth $(\mathrm{m})$ & \multicolumn{2}{c}{ Location } \\
\cline { 2 - 3 } & Sarah Island & Celery Top Island \\
\hline 1 & $9.0-20.2$ & $5.1-23.1$ \\
8 & $11.1-18.9$ & $9.0-19.8$ \\
\hline
\end{tabular}

* Recorded by maximum-minimum thermometers placed at $1 \mathrm{~m}$ and $8 \mathrm{~m}$ depths at two sites.

( $<110 \mu \mathrm{M}=46 \%$ saturation), except for surface waters near the Old River Mouth $(171 \mu \mathrm{M}=74 \%$ saturation $)$. The lowest recorded oxygen saturation level was at $20 \mathrm{~m}$ depth at Sarah Island (23\% saturation). However, low oxygen levels were not encountered during the February 1991 survey, hence did not consistently recur in the same month on an annual basis.

Because of the extremely high tannin content of the freshwater entering the Bathurst Harbour estuary, light penetration declined rapidly up the Bathurst Harbour estuary (fig. 6), and was extremely poor outside summer. Below the halocline, however, water was highly transparent in all months. Using data collected on 23 February 1991, light transmission was found to be highly correlated with salinity $\left(\mathrm{T}=2.523 \times 10^{0.0397 \times \mathrm{s}}\right.$, where $\mathrm{T}$ is percent transmission through a $1 \mathrm{~m}$ column of water (i.e. $100 \times \mathrm{I}_{n+1} / \mathrm{I}_{\mathrm{n}}$ where I is irradiance at $n$ metre depth) and $S$ is salinity $\left(\% 0_{0}, n=37\right.$, $\mathrm{R}^{2}=0.85$ ).

\section{Plankton}

The phytoplankton community in Bathurst Harbour has a low species density, particularly during the winter and spring months when the dinoflagellate Dinophysis acuminata Claparede \& Lachman occurs in bloom proportions. In the October and July surveys, D. acuminata comprised $>99 \%$ of phytoplankton numbers at the Bathurst Harbour and Placypus Point sites, with the diatoms Nitzschiasp. and Chaetocerossp. being the only other species recorded. During summer, two other dinoflagellates (Gyrodinium of. uncatenum Hulbert and Protoperidiniumcf. bipes (Paulsen)Balech) were almost as abundant as $D$. acuminata, with a number of diatoms also being present.

The number of phytoplankton species was related to the amount of marine water present. Algal species richness increased towards the western outlet of Bathurst Channel and in the months of warmer water temperatures (fig. 7). At the time of the February intrusion of marine water into Bathurst Harbour, there was little change in observed algal species richness along the estuary. This lack of an increase in species numbers towards Port Davey during summer may have been an artifact of the small sample sizes examined; a number of oceanic algae, such as the dinoflagellates Phalacroma rotundata Kofoid \& Michener, Ceratium massiliense (Gourret) Jörgensen and Ceratium furca (Ehrenberg) Dujardin, were collected in low numbers off 
Bathurst salinity
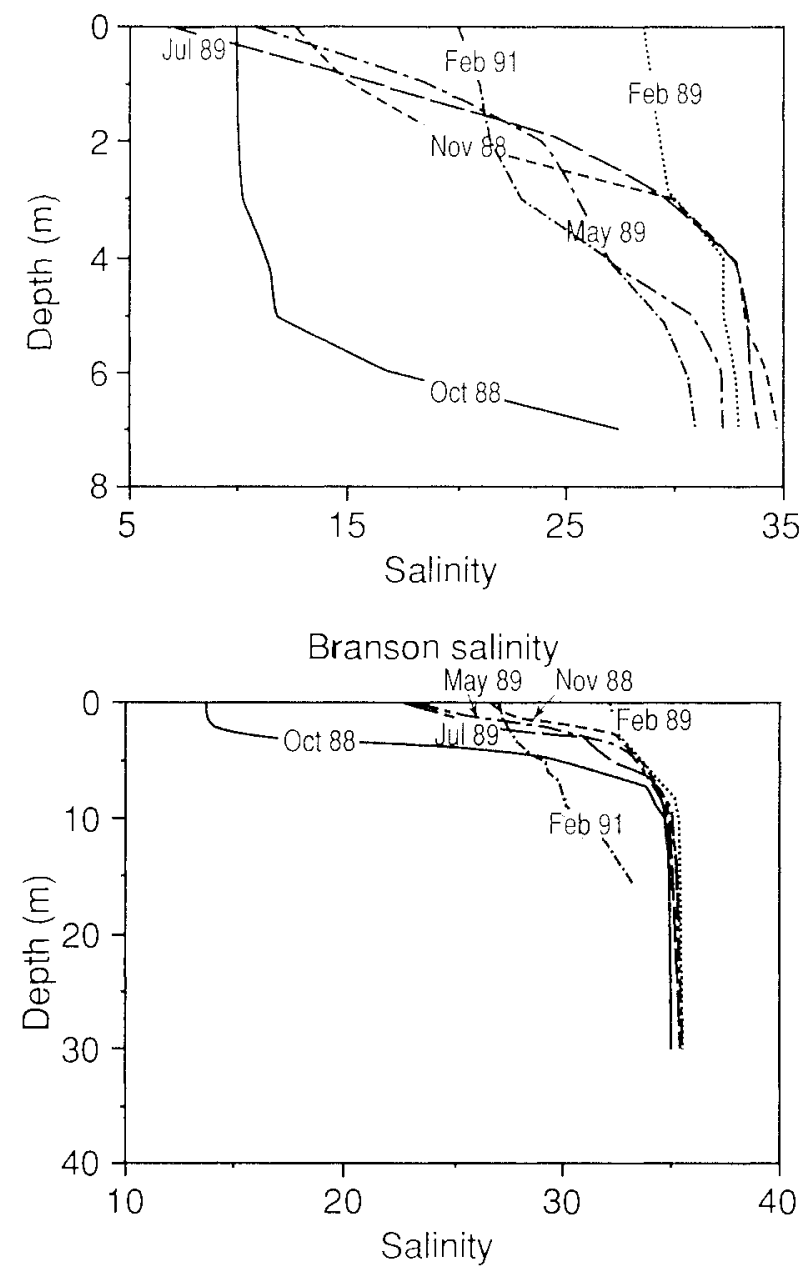

Sophia salinity

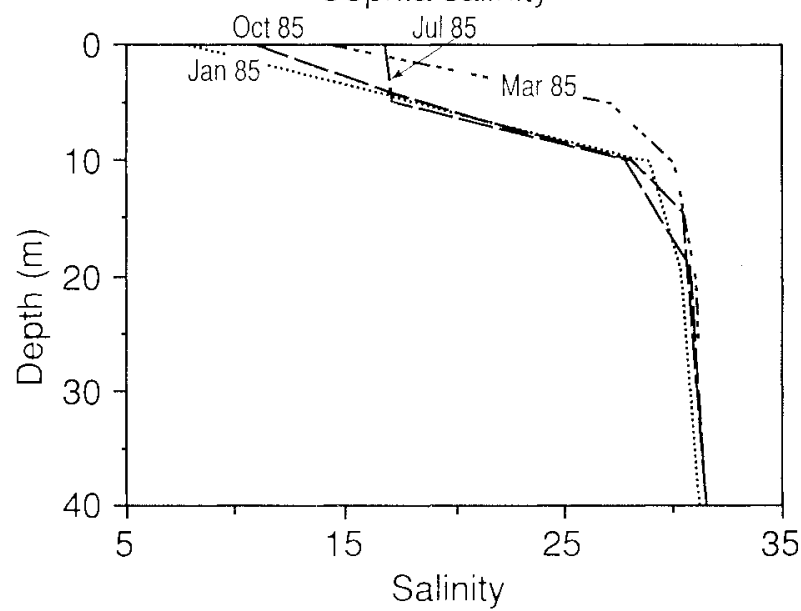

Bathurst temperature

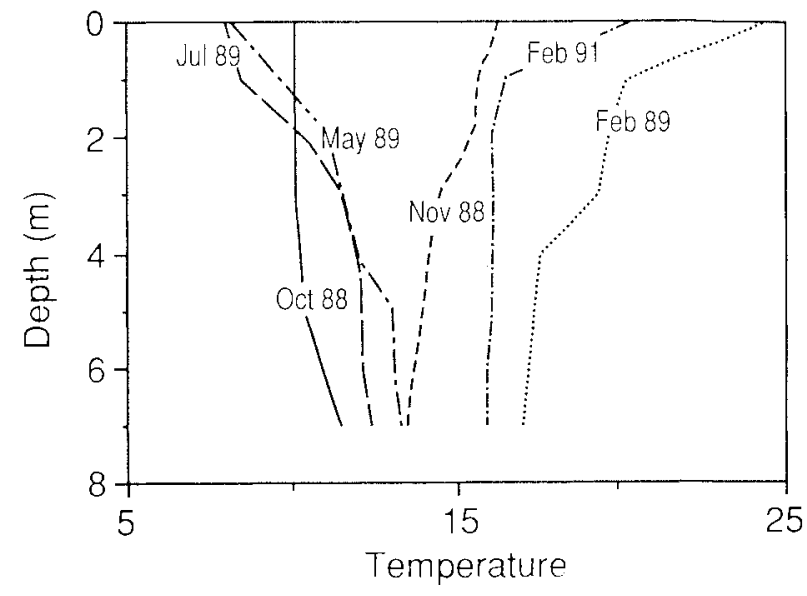

Branson temperature

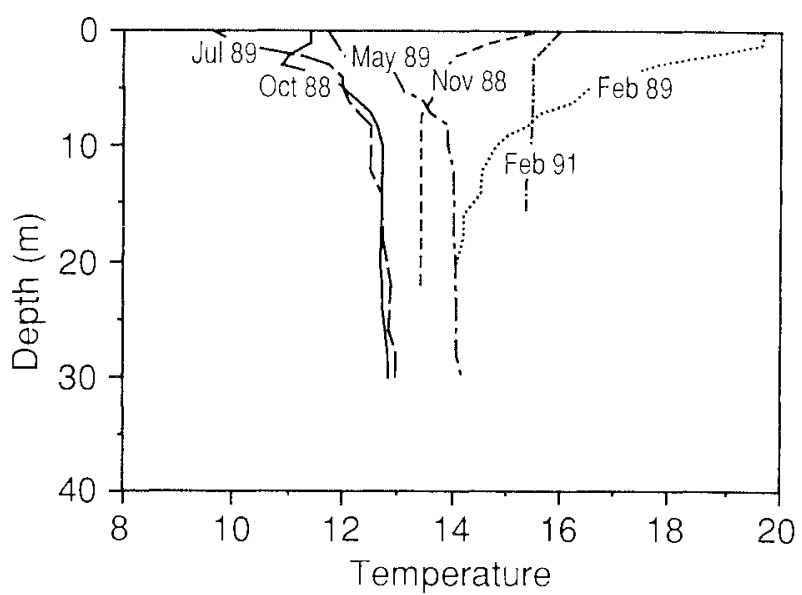

Sophia temperature

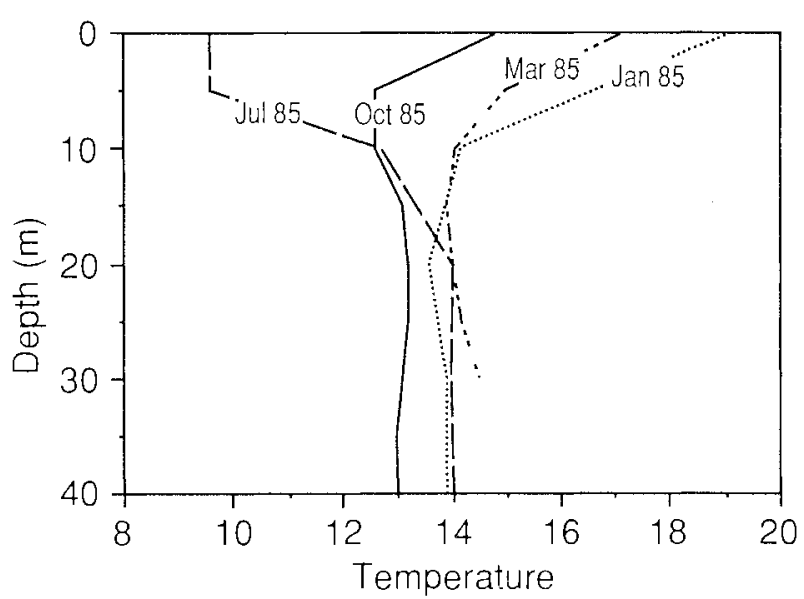

FIG. 5 - Depth profiles of temperature and salinity at sites in Bathurst Harbour (Bathurst Harbour 2) and Bathurst Channel (Branson), which are compared with a site in Macquarie Harbour (Sophia; Cresswell et al. 1989). 


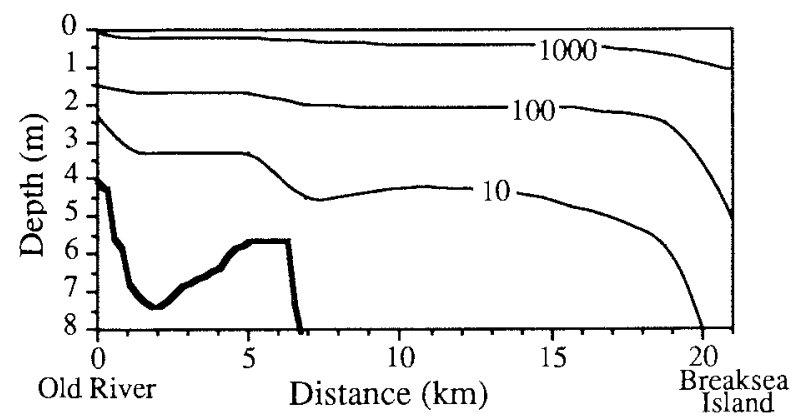

FIG. 6 - Water transparency profiles $\left(\mu E . \mathrm{m}^{-2} . \mathrm{s}^{-1}\right)$ along the Bathurst Harbour estuary from the Old River Mouth to Breaksed Island.
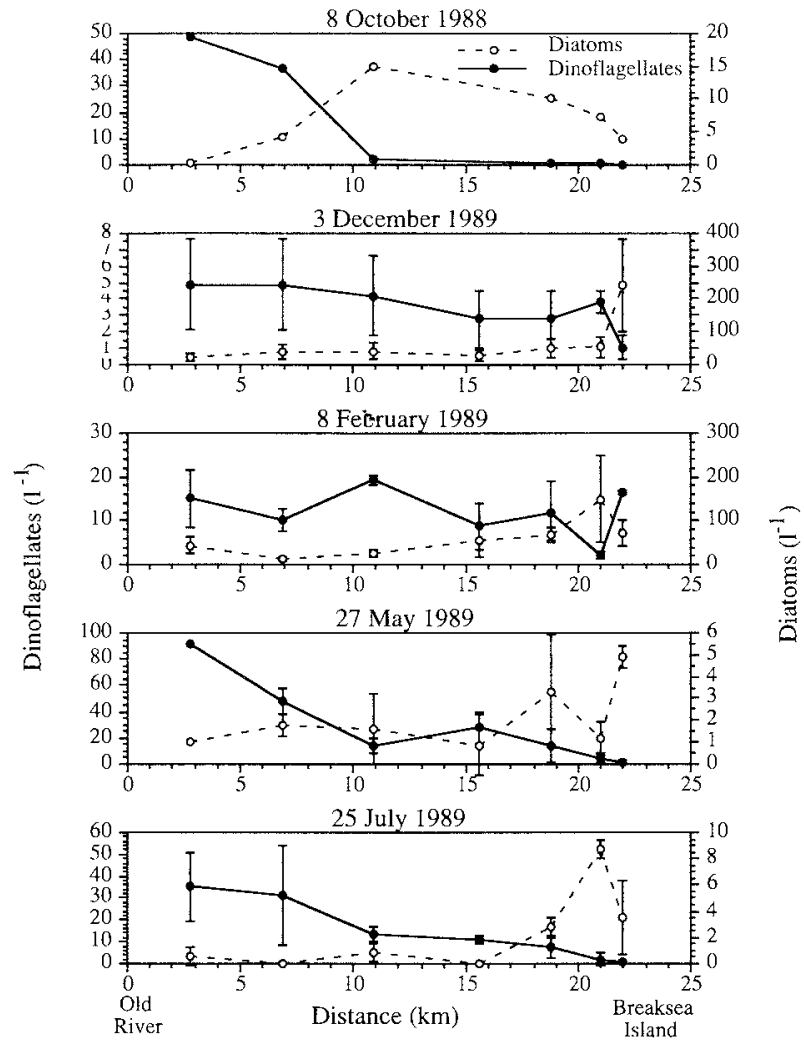

FIG. 8-Concentration $( \pm$ s.d.) of dinoflagellate and diatom cells in the Bathurst Harbour estuary on various sampling dates.

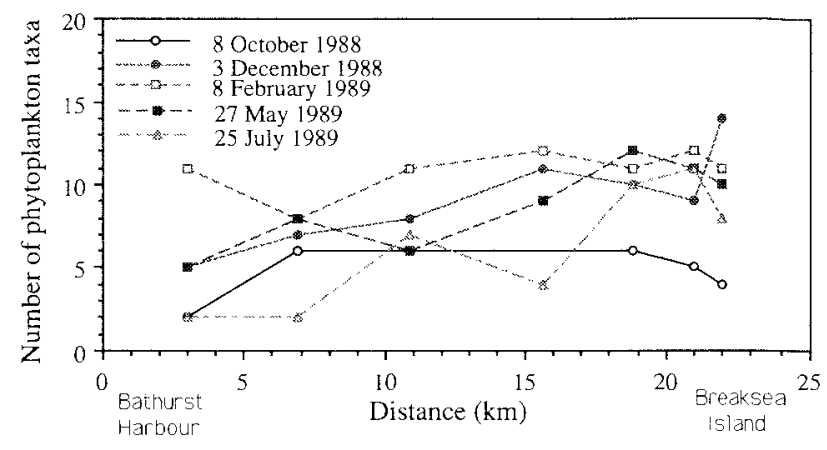

FIG. 7 - Number of phytoplankton taxa observed on microscope slides prepared from samples collected at sites in the Bathurst Harbour estuary on various dates.

Breaksea Island but not detected upstream of Sarah Island in Bathurst Channel, even during summer.

The two major components of the sampled phytoplankton, dinoflagellates and diatoms, showed almost mirror image patterns of abundance on both spatial and temporal scales (fig 8). Dinoflagellate numbers declined in importance from Bathurst Harbour towards Port Davey while diatoms showed the opposite trend. Dinoflagellates were also most abundant during the three surveys in the cooler months, whereas diatoms were present in large numbers $\left(>20 \mathrm{I}^{-1}\right)$ throughout the estuary only during summer (December and February). Many of the diatoms collected were benthic forms, possibly normally living attached to sediments, marine plants or suspended humic particles.

In contrast to the hydrological data, which showed that the pattern in February was markedly different from the patterns recorded on other sampling occasions, the plankton data indicated a dichotomy between the distribution of plankton in December/February and in May/July/October. This dichotomy is apparent for phytoplankton but is more clearly seen for zooplankton (figs 9 and 10).

Zooplankton biomass (fig. 9) and abundance (fig. 10) both peaked in December and February, but their patterns of distribution did not precisely correspond, because the dominant species in October and December, the copepod Gladioferens inermis Nicholls, was several times larger and more than an order of magnitude heavier than the major species from February to May, the copepod Oithona australis Nishida. Consequently, zooplankton biomass was highest

TABLE 2

Seasonal oxygen determinations $(\mu \mathrm{M})$ recorded in Bathurst Harbour on various sampling dates

\begin{tabular}{|c|c|c|c|c|c|c|c|c|c|c|c|c|c|c|c|c|c|c|}
\hline \multirow{2}{*}{$\begin{array}{l}\text { Date } \\
\text { Station* }\end{array}$} & \multicolumn{3}{|c|}{8 Oct 1988} & \multicolumn{3}{|c|}{27 Nov 1988} & \multicolumn{4}{|c|}{8 Feb 1989} & \multicolumn{4}{|c|}{27 May 1989} & \multicolumn{4}{|c|}{23 Feb 1991} \\
\hline & 1 & 3 & 5 & 1 & 3 & 5 & 1 & 3 & 5 & 8 & 1 & 3 & 5 & 8 & 1 & 3 & 5 & 8 \\
\hline \multicolumn{19}{|c|}{ Depth (m) } \\
\hline 0 & 285 & 286 & 275 & 250 & 251 & 200 & 171 & & & 63 & 266 & 268 & 258 & 250 & 243 & 240 & 224 & 202 \\
\hline 2 & 291 & & & 243 & & & & & & & 248 & 253 & 238 & 252 & 246 & 243 & 227 & 202 \\
\hline 4 & 286 & 274 & 260 & 107 & 236 & 237 & 106 & 73 & & 72 & & 242 & & 252 & 250 & 240 & 224 & 202 \\
\hline 6 & & & & & 233 & & & & 71 & & & 234 & 230 & & & 230 & 214 & 202 \\
\hline 7 & & 236 & & & & & & 102 & & & & & & & & 218 & 211 & 205 \\
\hline 10 & & & & & & 232 & & & & 75 & & & 232 & & & & 211 & 205 \\
\hline 15 & & & 258 & & & & & & 78 & 68 & & & & & & & & \\
\hline 25 & & & & & & & & & & 72 & & & & 251 & & & & \\
\hline
\end{tabular}

* 1 = Old River Mouth, 3 = Bathurst Harbour, 5 = Platypus Point and 8 = Sarah Island. 


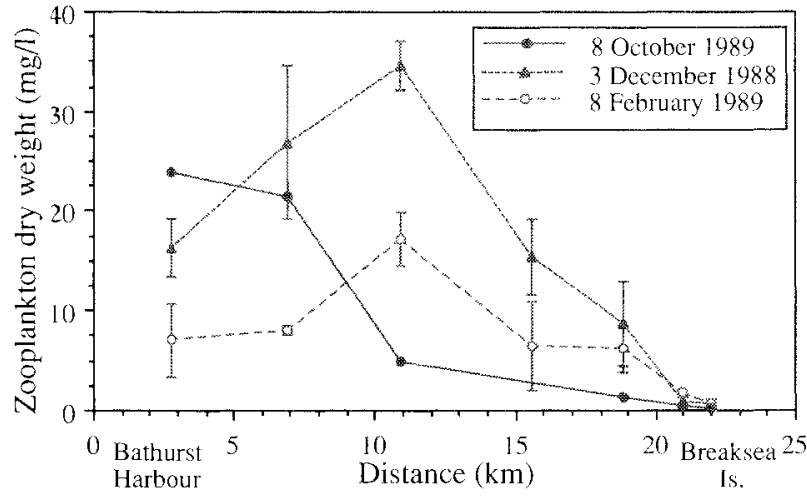

FIG. 9 - The mean biomass ( \pm s.d.) of zooplankton at sites in the Bathurst Harbour estuary on various sampling dates. Zooplankton biomass was negligible $(<1 \mathrm{mg} / \mathrm{l})$ at all sites on 27 May 1989 and 25 July 1989 so has not been shown here.

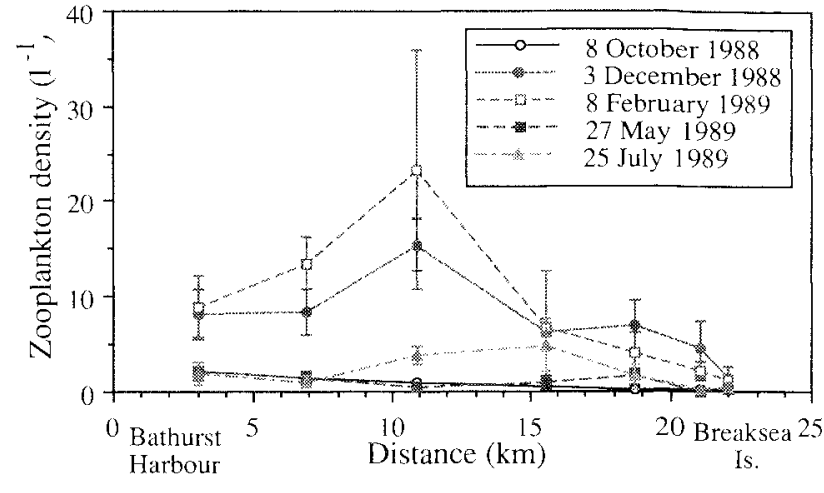

FIG. 10 - The mean abundance $( \pm$ s.d.) of zooplankton at sites along the Bathurst Harbour estuary on various sampling dates.
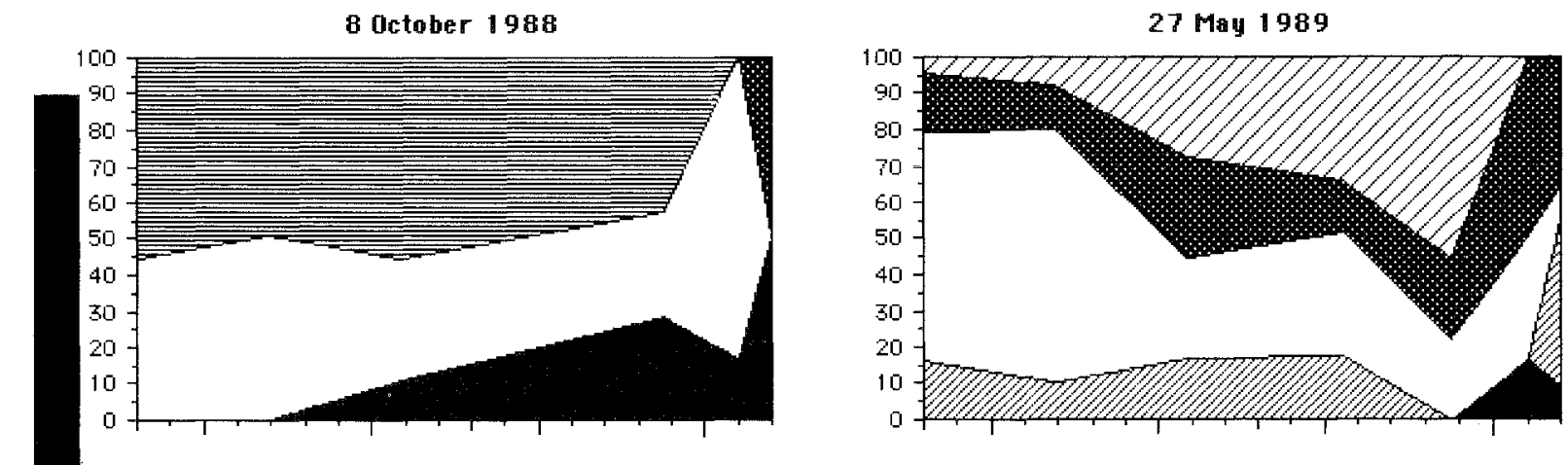

3 December 1988

\section{Jul y 1989}

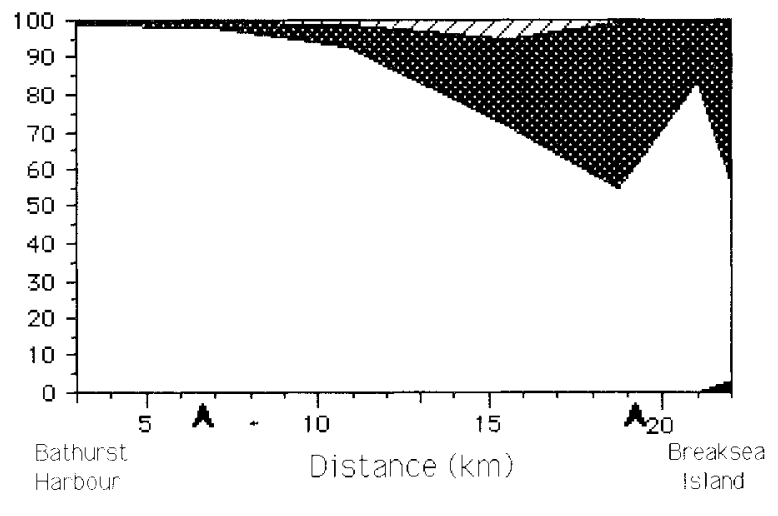

8 February 1989

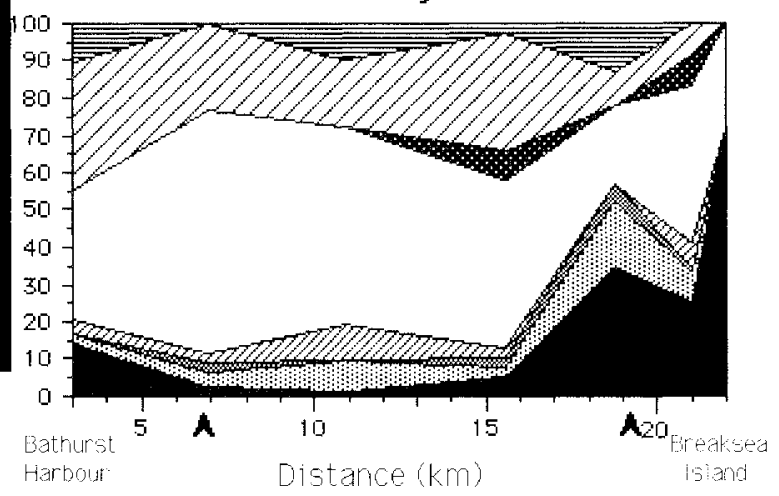

Fig. 11 - The relative abundance of major zooplanktonic taxa in samples collected at sites along the Bathurst Harbour estuary on various sampling dates. 
in December while zooplankton were most abundant in February. Zooplankton biomass was also very high in Bathurst Harbour during October, a time of relatively low zooplankton abundance. The low average body size and low numbers of zooplanktonic taxa in May and July resulted in the biomass of samples from those surveys being virtually undetectable $(<2 \mathrm{mg} / \mathrm{l})$.

The distribution of zooplankton biomass along the Bathurst Channel transect did not differ markedly between the two summer surveys, except that biomass had consistently decreased from December to February by $\approx 50 \%$ at all sampling sites (fig. 9). The maximum biomass of zooplankton, and also maximum animal numbers, were recorded at Farrell Point in Barhurst Channel.

During the two summer surveys, the zooplankton community was much more diverse than on the other three surveys, with a large meroplanktonic component (fig. 11); large numbers of bivalve and gastropod veligers and lesser numbers of polychaete, shrimp and crab larvae and hydromedusae were recorded in summer. The dominant copepod species Gladioferens inermis became less important than the cyclopoid Oithona australis between December and February. Prior to summer, G. inermis was virtually the only copepod species recorded from Bathurst Harbour and the eastern end of Bathurst Channel, while from February to July a number of other taxa, most notably Paracalanus indicus Wolfenden and Acartia sp., were present in addition to $G$. inermis and the dominant $O$. australis (fig. 11). As well as the two main copepod species, the appendicularian Oikopleura sp. was abundantly collected during the surveys. Oikopleura sp. was common throughout the Bathurst Harbour estuary between December and May, especially during summer. The category "other taxa" shown in figure 11 consisted largely of unidentified planktonic eggs and was most important towards Port Davey.

\section{DISCUSSION}

The data collected on 27 November 1988 and 25 July 1989 differed only slightly from Thomson's data (1978a,b) collected on 31 December 1977 and 20 July 1978 respectively. The two minor ways in which Thomson's surveys differed from the more recent ones in the same seasons were that more freshwater was present during the earlier surveys, and the bottom water in Bathurst Channel on 20 July 1978 was $1^{\circ} \mathrm{C}$ cooler than on 25 July 1989 . This difference in winter water temperatures possibly reflects a slight seasonal difference in the date on which water temperatures were recorded; the temperature of $11.5^{\circ} \mathrm{C}$ at Hixson Point on 20 July 1978 (Thomson $1978 \mathrm{~b}$ ) is above the $11.1^{\circ} \mathrm{C}$ minimum temperature recorded at $8 \mathrm{~m}$ depth at nearby Sarah Island (table 1). A more likely explanation for the temperature difference between years is that it reflects a real interannual difference in oceanic water temperatures off southern Tasmania; Harris et al. (1987: fig. 8) indicated that oceanic water temperatures off Tasmania were unusually low in 1978.

Although Thomson's 31 December 1977 data were referred to by him as summer data, it is now evident that the physico-chemical environment in the Bathurst Harbour estuary changes substantially within the summer period and also between years. The hydrological regime described by Thomson (1978a) in December 1977 did not differ greatly from that reported during the cooler months, whereas the major hydrological features in February 1989 were different to those recorded in winter, most notably because

(i) marine waters penetrated with little dilution throughout the estuary, except in waters immediately adjacent to rivers and creeks;

(ii) a strong thermocline existed near the surface;

(iii) visible light penetrated below $7 \mathrm{~m}$, the depth of the floor of Bathurst Harbour; and

(iv) oxygen saturation levels were low.

In this context, it should be noted that oxygen determinations in February 1989 may include some inaccuracy due to a lengthy period of time (three weeks) berween the collection and laboratory analysis of samples. Samples collected on other surveys were subjected to a similar threeweek time delay between collection and analysis, but they were stored at lower temperatures. It is nevertheless unlikely that oxygen concentration levels would have been grossly $(>20 \%)$ inaccurate because surface samples collected on the same summer day as other samples from near the mouth of the Old River showed relatively high oxygen saturation levels. Water flowing out of the Old River was presumably near full saturation, hence surface samples collected at this station would be expected to be higher than at other sites.

Only one other estuary in Australia, Macquarie Harbour in western Tasmania, has physical and hydrological characteristics which are at all comparable with Bathurst Harbour. The Macquarie Harbour and Bathurst Harbour estuaries both have

(i) highly stratified waters, with a darkly-stained brackish surface layer, and

(ii) relatively deep ( $>30 \mathrm{~m}$ ) basins, occupied by saline water, which are separated from the open sea by shallower areas.

Similarities and differences between the two systems are both apparent when the results from the present study are compared with those from seasonal surveys of Macquarie Harbour (Cresswell et al. 1989). To do this, we will refer to the sections in the Bathurst system (figs 2, 3 and 4) and in the Macquarie system (Cresswell et al. 1989: fig. 2). These are complemented by the temperature and salinity data for sites representative of Bathurst Harbour (Bathurst Harbour Station 2), the deep part of Bathurst Channel (Branson Station), and the deep part of Macquarie Harbour (Sophia Station). These are presented as depth profiles of temperature and salinity in figure 5 .

Cresswell et al. (1989) identified three layers in Macquarie Harbour:

(i) a surface layer in the upper $10 \mathrm{~m}$ dominated by seasonal heating and cooling and river runoff;

(ii) a long-residence-time layer centred at $20 \mathrm{~m}$, having a small annual temperature range, low oxygen content and a peak in nitrate values; and

(iii) a deep marine layer of salinity $\approx 31 \%$ in which the oxygen content increased with depth.

Figure 5 shows that the marine bottom layer in Bathurst Channel $(\approx 35 \%$ o) is more saline than in Macquarie Harbour which is probably a function of the respective volumes and exchanges with the ocean of the two systems. The Bathurst surveys give no indication of a mid-layer. The deep water in Bathurst Channel has somewhat paradoxical characteristics, possessing an ocean-type salinity, suggesting easy interaction with the ocean, and a relatively stable temperature, suggesting that it has its own identity.

When the Macquarie Harbour and the Bathurst Harbour and Channel temperature and salinity profiles (fig. 5) are closely compared, it can be seen that, apart from the unusual 
October and February situations that are most readily apparent in the shallow Bathurst Harbour, there are many similarities at the two deep stations, such as the small temperature range at $30 \mathrm{~m}$, the $10^{\circ} \mathrm{C}$ range of surface temperatures and the profile shapes.

The lowest levels of dissolved oxygen at Macquarie Harbour have been shown (Cresswell et al. 1989: figs 2 \& 3)) to be $\approx 100 \mu \mathrm{M}$ at $\approx 20 \mathrm{~m}$ depth, with little change between the four surveys. By comparison, dissolved oxygen was consistently $\approx 250 \mu \mathrm{M}$ in the Bathurst Harbour estuary, apart from February 1989 when oxygen levels decreased to $<50 \mu \mathrm{M}$. 'The low values of oxygen saruration in February may be important to the biota, probably preventing many marine animals from reaching Bathurst Harbour at that time (Edgar 1991b).

Nitrate levels were gencrally much lower at Bathurst Harbour than Macquarie Harbour, ranging from $<0.1$ to $3.9 \mu \mathrm{M}$ at Bathurst Harbour but generally falling between 1.4 and $10 \mu \mathrm{M}$ (i.e. 20 and $150 \mu \mathrm{g} / \mathrm{l}$ ) at Macquarie Harbour (Cresswell et al. 1989). One hypothesis which explains the elevated nitrate levels at Macquarie Harbour is that there is a large nutrient input from the towns of Queenstown and Strahan; however, a more important source of nutrients is probably the freshwater entering Macquarie Harbour from the Gordon River. Most of this water has been discharged from the deeper sections of the Serpentine Impoundment, and consequently has a high nutrient load. Cresswell et al. (1989) indicated that the concentration of nitrate in Gordon River water entering Macquarie Harbour is $\approx 100 \mu \mathrm{g} / \mathrm{l}$ ( $=7 \mu \mathrm{M})$, an order of magnitude higher than the level of $\approx 0.5 \mu \mathrm{M}$ for water from the Old River entering Bathurst Harbour.

The surface nitrate levels at Bathurst Harbour are amongst the lowest for any estuary which has been investigated. While it is possible that the chemocline in Bathurst Harbour overturns for short periods, such as occur in Port Hacking, NSW (Rainer \& Griffiths 1980), an estuary in which surface nitrate levels fall below $0.1 \mu \mathrm{M}$ in all seasons of the year is extremely unusual; we could find no reference to another estuary worldwide with this condition. A low nutrient estuary such as this could presumably only occur when several factors combine:

(i) little nutrient input into streams within the catchment area because of inert surrounding rocks;

(ii) no anthropogenic sources of nutrients such as fertilisers, sewage or the nutrient-rich bottom waters of dams;

(iii) a highly stratified system, with no major upwelling; and (iv) high densities of phytoplankton which rapidly absorb nutrients and ultimately cause them to be transported from surface waters to bottom sediments.

Although no current or tidal data were collected during the investigation, the salinity data allow very rough estimates of water residence times in the system to be made. The residence time of water above the halocline in Bathurst Harbour is probably relatively low $(<1 \mathrm{mo})$. Most of the brackish water present in early October had been flushed from the system by late November, and all of the brackish water present at that time had disappeared by February. The maximum residence time of surface water in Bathurst Harbour is therefore considerably less than three month.s. It is, however, possible that the residence time of water in the top $2 \mathrm{~m}$ is as low as one week. Bathurst Harbour has a semidiurnal tide with an atmospheric pressure component of equivalent magnitude to the lunar component. The tidal range is generally $\approx 0.3 \mathrm{~m}$, although most of the water moving into Bathurst Channel during each tidal cycle is probably returned during the same cycle. Because of the greater freshwater throughput during winter, surface waters should have lower residence times in winter than in summer.

The saline water near the bottom of Bathurst Harbour was isolated from marine water in Bathurst Channel on four of the five survey periods, with replenishment (i.e. an increase in salinity) occurring on several occasions during the period of the study. The salinity profile in Bathurst Harbour was generally quite stable during the ten-day periods in which field trips were carried out, hence the bottom waters were probably isolated for considerable periods of time, possibly in the order of three months.

The salinity, nutrient and light transects all change most rapidly near the western entrance of Bathurst Channel (figs 3, $4 \& 6$ ). This region corresponds to the area at which planktonic assemblages rapidly change (fig. 11), and the boundary between marine-influenced Port Davey invertebrate and fish assemblages and Bathurst Harbour estuarine assemblages (Edgar 1984, 1991a,b). The overlap zone between the marine and estuarine ecosystems can be generally defined as the small area of Bathurst Channel between Sarah Island and Hammond Point on the north shore, and Forrester Point and Turnbull Head on the south shore. This boundary is most likely a direct consequence of local water circulation patterns; west of the boundary, waters probably receive regular mixing with the marine waters of Port Davey, while east of the boundary estuarine water moves in and out with the tide but receives little mixing. This boundary also approximately corresponds with the location at which the floor of the estuary changes from sand to silt.

A primary characteristic of the Bathurst Harbour estuary is the very low diversity of planktonic taxa, with a few species thriving in extremely high densities. In addition to the data presented here, a low algal species richness is indicated by the very few dinoflagellate cyst species in the area. Sediment cores collected by Bolch \& Hallegraeff (1990) from the Bathurst Harbour estuary contained only Gonyaulax grindleyi, Scrippsiella trochoidea, Protoperidinium oblongum and Polykrikos schwartzii, a low number of taxa compared with cores collected elsewhere in Tasmania, including the Derwent and Huon estuaries. Amongst 11 sites around the Tasmanian coast, only Macquarie Harbour had a similarly low number of dinoflagellate cyst taxa (Bolch \& Hallegraeff 1990). This low algal species richness is probably a function of low light and nutrient levels which provide an unsuitable environment for the survival of most phytoplankton species in the estuary. The abundance and species composition of phytoplankton has been shown in numerous studies to be greatly influenced by the concentration and relative proportions of plant nutrients (Tilman 1977, Sanders et al. 1987, Doering et al. 1989). G. Hallegraeff (pers. comm.) has also suggested that trace elements may be limiting in the estuary because they probably remain strongly bound to the large quantities of humic material dissolved in the Bathurst Harbour waters.

In a recent review, Cushing (1989) summarised a number of general differences between planktonic communities in stratified and unstratified waters throughout the world. He noted that phytoplankton communities in strongly stratified waters are characterised by a predominance of dinoflagellates while diatoms are most common in weakly stratified water. Cushing (1989) postulated that, because dinoflagellates are mobile, they can position themselves near the water surface 
in stratified waters during the day to exploit the high light levels. Poorly stratified waters, on the other hand, are dominated by diatoms because these algae reproduce quickly and have lower photosynthetic requirements than dinoflagellates. Surface rurbulence in unstratified water was thought to cause large numbers of phytoplankton to be transported to depths with little light for growth. Cushing (1989) also noted that zooplankton biomass rapidly increases whenever thermoclines in temperate waters are overturned in spring, the time when phytoplankton communities change from being dominated by dinoflagellates to being dominated by diatoms. He interpreted these patterns in terms of the findings of Azam et al. (1982) that dinoflagellates were rarely a major food source for herbivorous zooplankton. In environments dominated by dinoflagellates, the major trophic pathway to zooplankton is an indirect one, through bacteria, heterotrophic flagellates and ciliates, which is largely fueled by the organic matter excreted by the dinoflagellates. Because of the number of trophic links through this microbial food loop, it supports much lower zooplankton production than the direct diatom-copepod trophic linkage.

The patterns of distribution of planktonic organisms in the Bathurst Harbour estuary generally agreed with these worldwide patterns; dinoflagellates declined in importance from the stratified waters of Bathurst Harbour to the turbulent waters of Port Davey, and also from the winter season, when a well-defined halocline was present in Bathurst Harbour, to the summer season, when a halocline was lacking.

The timing of the Bathurst Harbour phytoplankton and zooplankton successions did not agree, however, with the classical model, because zooplankton had increased to high biomass levels by October 1988. Therefore, the rapid buildup in zooplankton biomass (and presumably also production) in spring must have been fueled by dinoflagellates or unidentified smaller organisms rather than by diatoms, or else the phytoplankton community was extremely variable in time and space, and not adequately described using samples collected at bimonthly intervals.

In common with other systems, dinoflagellates were unlikely to have provided much direct food for zooplankton in Bathurst Harbour, even during the period when dinoflagellates occurred in high abundances. The major dinoflagellate species, Dinophysis acuminata, appeared much too large (30-50 $\mathrm{mm}$ long) to be ingested by zooplankton, hence a microbial food loop consisting of bacteria, small $(<20 \mu \mathrm{m})$ phytoplankton and ciliates was probably providing most of the food for zooplankton during the dinoflagellate blooms. This hypothesis is supported by the large numbers of appendicularians present in Bathurst Harbour; this animal group is known to feed almost exclusively on organisms less than $5 \mu \mathrm{m}$ (Knoechel \& Steel-Flynn 1989).

The reasons for the low densities of dinoflagellates in summer and low densities of diatoms in other periods of the year remain to be determined. Cushing's hypothesis (1989) does not explain the decline in dinoflagellate densities in summer because the estuary is quite shallow, with considerable light penetrating to the bed of the estuary in February. Moreover, the estuary was stratified on 3 December 1988, when dinoflagellate numbers were low. The abundances of dinoflagellates were, therefore, more likely to have been limited by a lack of nutrients or trace elements rather than of light during summer, possibly because diatoms were more efficient at utilising the available nutrients, due to their greater surface area/volume ratio. It should be noted, however, that nitrate concentrations were not detectably lower in summer than during spring, when dinoflagellate numbers were high. Therefore a deficiency of phosphates or trace elements rather than a lack of nitrates may have restricted dinoflagellate growth.

The concentration of diatoms was probably severely limited in Bathurst Harbour during the winter months because of the lack of accessible nitrogen in surface waters and the lack of light penetration to the deeper waters. Because dinoflagellates are motile, they would not be similarly restricted; they can move between the well-lit surface layer and the nitrate-rich waters below the chemocline (Eppley et al. 1968, Blasco 1978). The few phytoplankton samples collected during the study from waters below $2 \mathrm{~m}$ depth contained very few organisms; dinoflagellates were clearly concentrated within $1 \mathrm{~m}$ of the surface during the day. Other possible explanations for the low numbers of diatoms are that growth was limited by a deficiency of silica, of phosphorus or of trace elements in the estuary.

While the high abundance and biomass of copepods during summer presumably depended on diatom production, the reasons for the increase in copepod abundance prior to the October survey remain equivocal. Dinoflagellate densities were high throughout winter; it is therefore possible that picoplankton and nanoplankton were sufficiently productive during winter to sustain increased copepod production. As well as utilising exudates from dinoflagellates, planktonic bacteria may also have been directly utilising the leached organic compounds present in freshwater entering the estuary. The quantity of dissolved organic compounds entering Bathurst Harbour must be large, judging by the considerable amount of foam present along surface slicks in the area.

\section{ACKNOWLEDGEMENTS}

This and the associated studies would not have been possible without the advice and support of a number of people and organisations. In particular, we would like to thank Steven Smith and the Department of Parks, Wildlife and Heritage for providing funding, logistical assistance and advice; Derek Shields, Mary O'Doherty, Phil Wyatt, Mark Holdsworth and Chris Arthur for their help in the field, under often trying conditions; Prof. M. Stoddart, David Ritz and the Zoology Department, University of Tasmania, for laboratory space and the use of equipment; Dennis Mackey, Bruce Barker and Ron Plaschke (CSIRO Division of Oceanography) for hydrological advice, sample analysis and the loan of oceanographic equipment; and Mike Johnson (Department of the Environment) for undertaking the nitrate and nitrite analyses of water samples. The study of plankton could be conducted only because of the assistance, and use of equipment, provided by Gustaaf Hallegraeff(CSIRO Division of Fisheries Research). The taxonomic help of Dave McKinnon (Australian Institute of Marine Science) was also much appreciated, as were comments on the manuscript by Gustaaf Hallegraeff and David Ricz. 


\section{REFERENCES}

AZam, F., Frbchel, T., Field, J.G., Gray, J.S., Meyer-Reil, L.A. \& THINGSTAD, F., 1982: The ecological role of water-column microbes in the sea. Mar. Ecol. Prog. Ser. 10: 257-263.

BAKER, W.E. \& AHMAD, N., 1959: Re-examination of the fjord theory of Port Davey, Tasmania. Pap. Proc. R. Soc. Tasm. 93:113-115.

BlasCo, D., 1978: Observations on the diel migration of marine dinoflagellates off the Baja California coast. Mar. Biol. 46: $41-47$.

Bolch, C.J. \& Hallegraeff, G.M., 1990: Dinoflagellate cysts in recent matine sediments from Tasmiania, Australia. Botanica Marina 33: 173-192.

BuckNeY, R.T. \& TYler, P.A., 1973: Chemistry of Tasmanian Inland Waters. Int. Revue Ges. Hydrobiol. 58: 61-78.

Cresswell, G.R., Edwards, R.J. \& BarkeR, B.A., 1989. Macquarie Harbour, Tasmania - Seasonal Oceanographic surveys in 1985. Pap. Proc. R. Soc. Tasm. 123: 63-66.

CusHing, D.H., 1989. A difference in structure between ecosystems in strongly stratified waters and those that are only weakly stratified. J. Plankton Res. 11: 1-13.

Dolring, P.H., Oviatt, C.A., Beaity, L.L., Banzon, V.F., Rice, R., Keli.y, S.P., Sullivan, B.K. \& Frithsen, J.B., 1989. Structure and function in a model coastal ecosystem: silicon, the benthos and eutrophication. Mar. Ecol. Prog. Ser. 52: 287-299.

EDGAR, G.J., 1984: Marine life and potential marine reserves in Tasmania. Part 2. Nat. Parks Wildl. Serv. Occ. Pap. 7: 1102.

EDGAR, G.J., 1991a: Distribution patterns of mobile epifauna associated with rope fibre habitats within the Bathurst Harbour estuary, south-western Tasmania. Estuar. Coast. Shelf Sci. in press.

EDGAR, G.J., 1991b: Seasonal distribution patterns of fishes within the Bathurst Harbour estuary, south-western Tasmania. Pap. Proc. R. Soc. Tasm. 125: 37-44.

Eptiey, R.W., Holm-HaNsen, O. \& STrkicki.and, J.D.H., 1968: Some observations on the vertical migration of dinoflagellates. J. Phycol. 4: 333-340.

Harris, G., Nilsson, C., Cifmantson, L. \& Thomas, D., 1987 : The water masses of the east coast of Tasmania: seasonal and interannual variability and the influence on phytoplankton biomass and productivity. Aust. J. Mar. Freshu. Res. 38: 569-90.

KNoechel, R. \& Stfel-FlynN, D., 1989: Clearance tates of Oikopleura in cold coastal Newfoundland waters: a predictive model and its trophodynamic implications. Mar. Ecol. Prog. Ser. 53: 257-266.

Major, G.A., Dal Point, G., Kiyf, J. \& Newfli, B., 1972 : Laboratory techniques in marine chemistry. A manual. CSIRO Aust. Div. Fish Oceanogr. Rep. 51, 60 pp.

NYAN TAW, \& D.A. RrTz, 1978: Zooplankton distribution in relation to the hydrology of the Derwent River estuary. Aust. J. Mar. Freshw. Res. 29: 763-775.

NYAN TAW, \& D.A. RIY, 1979: Influence of subantarctic and subtropical oceanic water on the zooplankton and hydrology of waters adjacent to the Derwent River estuary, southeastern Tasmania. Aust. J. Mar. Freshw. Res. 30: 179-202.

ONG, J.E., 1967: A general survey of primary productivity and the spatial and temporal distribution of the surface waters of the Derwent River estuary. Unpubl. Hons thesis, University of Tasmania.

ONG, J.E., 1969: An interesting and possibly new species of Coreaceus (Cyclopoida, Copepoda, Crustacea) from Port Davey. In McIntosh, B. (Ed.): PORT DAVEY REPORT. Unpubl. rep., Tasmania University Biological Sociery: 22-23.

RaINER, S.F. \& Griffiths, F.B., 1980: Hydrology of an estuary with periodic deoxygenation. CSIRO Aust., Div. Fish. Oceanogr. Rep. 117.

Sanders, J.G., Cibik, S.J., D'Elia, C.F. \& Bornton, W.R., 1987: Nurrient enrichment studies in a coastal plain estuary: changes in phytoplankton species composition. Can.J. Fish. Aquat. Sci. 44: 83-90.

THOmson, J., 1978a: Hydrological survey and shellfish inventory at Port Davey. SW Tasm. Res. Surv. Disc. Pap. 13: 1-11.

THomson, J., 1978b: Hydrological survey, Port Davey Winter 1978. SW Tasm. Res. Surv. Disc. Pap. 18: 1-14.

TII.MAN, D., 1977. Resource competition between planktonic algae: an experimental and theoretical approach. Ecology 58: 338 348.

(accepted 3 May 1991) 